\title{
Epidemiological and cytological aspects of the cervix in women from the Diourbel region (Senegal) cervical smear screening
}

\author{
Amadou Ndiade ${ }^{1 *}$, Ibou Thiam², Abdou Karim Diallo ${ }^{3}$, Ange Lucien Diatta ${ }^{4}$, \\ Fabrice Senghor ${ }^{4}$, Omar Faye ${ }^{5}$
}

\begin{abstract}
${ }^{1}$ Laboratory of Clinical Cytology, Cytogenetics, Reproductive Biology and Human Development, Heinrich Lubcke Regional Hospital of Diourbel, Senegal

${ }^{2}$ Laboratory of Anatomy Cytology Pathology, Faculty of Medicine, Pharmacy and Dentistry, Cheikh Anta Diop University, Dakar, Senegal

${ }^{3}$ Gynecological and Obstetric Clinic, Le Dantec Hospital, Dakar, Senegal

${ }^{4}$ Department of Biology and Functional Exploration, FRU of Health Sciences, Assane Seck University of Ziguinchor ${ }^{5}$ Histology-Embryology Laboratory, Department of Biology and Functional Explorations, Faculty of Medicine, Pharmacy and Odontology, Cheikh Anta Diop University, Dakar, Senegal
\end{abstract}

Received: 25 August 2020

Revised: 04 October 2020

Accepted: 05 October 2020

\section{*Correspondence:}

Dr. Amadou Ndiade,

E-mail: amadou.ndiade@uadb.edu.sn

Copyright: ( ) the author(s), publisher and licensee Medip Academy. This is an open-access article distributed under the terms of the Creative Commons Attribution Non-Commercial License, which permits unrestricted non-commercial use, distribution, and reproduction in any medium, provided the original work is properly cited.

\section{ABSTRACT}

Background: Objectives of the study were to record the results of uterine cervical smear tests of women in the Diourbel region to compare epidemiological data with the results of uterine cervical smear tests.

Methods: This was a retrospective study of 201 satisfactory cervical smears performed in the period from 01 December 2018 to 01 December 2019 at the laboratory of the regional hospital Henrich Lubcke of Diourbel. All women with a satisfactory smear were included in our study, so we classified patients according to age and parity.

Results: The mean age of the patients was 38.41 years with a standard deviation of 11.51 years. The extremes were 15 and 64 years. The age group (30-40 years) was in the majority at $32.34 \%$. Multiparous patients were in the majority, accounting for $43.28 \%$. The cervix was macroscopically healthy in $61.19 \%$ of patients and inflammatory in $12.94 \%$. There was $18.41 \%$ low-grade squamous intraepithelial lesion (LSIL), high-grade squamous intraepithelial lesion (HSIL) accounted for $1 \%$ of smears. A statistically significant relationship existed between parity and smear result with $\mathrm{p}<0.01$.

Conclusions: Cervical cancer is one of the most fatal cancers in women and the smear remains the safest and most effective means of prevention.

Keywords: Cervical smear, Dysplasia, Cervical cancer

\section{INTRODUCTION}

The only screening method for cervical abnormalities until the last few years was the Papanicolaou smear or cytological examination (cervico-vaginal smear replaced by the term cervical smear). In high-income countries where the smear has been used for routine screening for more than 30 years, this intervention has been associated with a significant reduction in cervical cancer morbidity and mortality. ${ }^{1}$

With 528,000 new cases each year, cervical cancer is the fourth most common cancer in women worldwide, after breast, colorectal and lung cancer, particularly in lowresource countries in sub-Saharan Africa. It is also the 
fourth most common cause of cancer death $(266,000$ deaths in 2012) among women worldwide. ${ }^{3}$ Cervical cancer is the second most common cancer among women in less developed regions and is the leading cause of cancer death among women in Senegal. Because of its high cost, cervical cancer is the leading cause of cancer death among women in Senegal. ${ }^{4}$

Anogenital human papillomavirus (HPV) infection is the most common sexually transmitted infection in the United States, with a prevalence of 70 million cases and an incidence of 14 million cases per year. ${ }^{5-7}$ Fifteen high-risk (HR) HPV genotypes can cause cancer of the cervix, anus, penis, vagina, vulva and oropharynx. ${ }^{8}$ Among these, the HPV-16 and HPV-18 subtypes are by far the most common in cervical cancer, representing for about $70 \%$ of cervical cancers, the other HR-HPV subtypes $(31,33,35$, $39,45,51,52,56,58,59,68,73$ and 82) represent the remainder. ${ }^{9}$ HPV-16 accounts for approximately $95 \%$ of HPV positive oropharyngeal cancers. ${ }^{10}$ The low-risk persistent HPV-6 and HPV-11 genotypes cause most anogenital warts and respiratory papillomatosis, but are rarely associated with cancer. ${ }^{8}$

Our objective were to record the results of uterine cervical smear tests of women in the Diourbel region to compare epidemiological data with the results of uterine cervical smear tests.

\section{METHODS}

This is a retrospective study of 201 satisfactory cervical smears performed in the Henrich Lubcke Regional Hospital in Diourbel from 01 December 2018 to 01 December 2019.

\section{Patients}

All women with a satisfactory smear were included in our study, so we classified the patients according to age and parity, meaning: nulliparous: no children, primiparous: a child, multiparous: 2 to 3 children and large multiparous: 4 children and more.

Smears taken outside the hospital and unsatisfactory smears were excluded from the study.

\section{The cervico-uterine sampling}

The cervico-uterine sampling, made in the laboratory of the regional hospital Henrich Lubcke in Diourbel, was carried out according to the following procedure: registration of the patient on arrival, the patient was registered in a register with an identifying number, second name, first name, age, origin and billing number. After this step, a receipt with the registration number was given to the patient to be presented on the day the results are to be retrieved; and interrogation was carried out on the basis of the survey form.

\section{Method of sampling}

After the interrogation, for each patient the following were used: an Ayre spatula (or a cytobrush for postmenopausal women), 2 blades bearing an object marked with their name and a sterile speculum. The patient lied in the gynecological position to collect the specimen. The speculum was positioned to highlight the cervix. With the spatula, two samples were taken: the first concerns the ectocervix and the second the endocervix. Each specimen was spread on a slide and fixed by spraying the ectocervix or hairspray.

\section{Coloration}

The coloration was done according to Papanicolaou technique.

\section{Interpretation}

Satisfactory smears are smears with an abundant epithelial cell population (covering $20 \%$ of the slide) of intact morphology, corresponding to squamous (ectocervix), glandular (endocervix) or metaplastic cells without inflammatory reaction or excessive bleeding. These are smears that cannot be reliably analyzed for the following reasons: paucicellar swabs; dense inflammatory or haemorrhagic lesions masking the epithelial elements.

\section{Ethical consideration}

The study protocol was approved by the Ethics Committee of the faculty of medicine, pharmacy and odontology in Cheikh Anta Diop University, Dakar, Senegal. A written informed consent was taken from all participants.

\section{Statistical analysis}

The collected data were entered into the Sphinx software and the analysis was carried out with the Epi info 7.2 software.

\section{RESULTS}

The mean age of the patients was 38.41 years with a standard deviation of 11.51 years. The extremes were 15 and 64 years. The median age was 38.00 years. The mode was 30 years.

The age group (30-40 years) was in the majority at $32.34 \%$ (Figure 1).

The majority of patients had no symptoms, the indication for smears for them was routine screening. Nevertheless, we found cases where the indication was metrorrhagia.

Multiparous patients were in the majority followed by large multiparous patients (Figure 2). 
The cervix was macroscopically healthy in $61.19 \%$ of patients and inflammatory in $12.94 \%$.

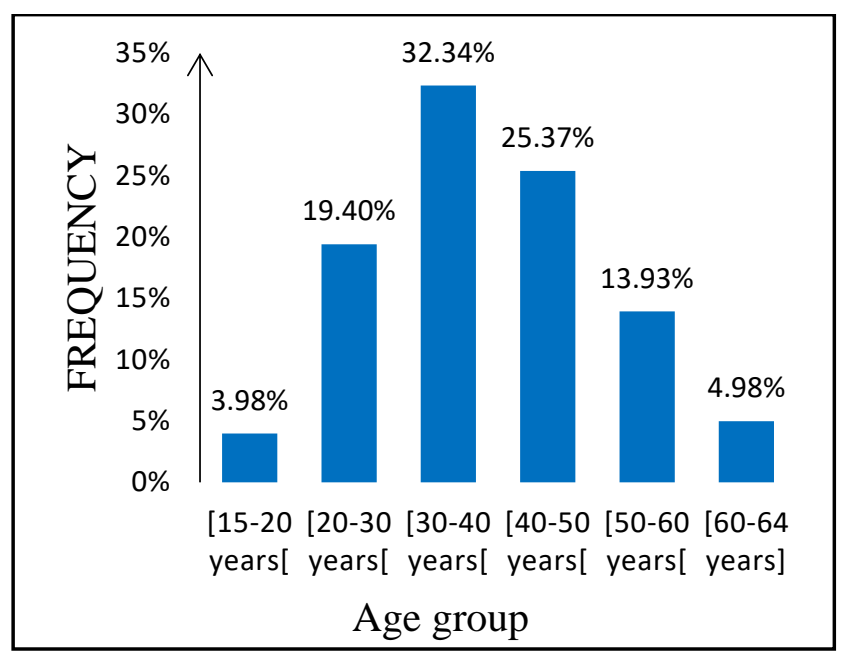

Figure 1: Age group.

There were $18.41 \%$ low-grade squamous intraepithelial lesion (LSIL) (37 patients), 04.48\% atypical squamous cells of undetermined significance (ASCUS) (09 patients), $02.99 \%$ atypical squamous cells of high grade (ASC-H) (06 patients), and $01.00 \%$ high-grade squamous intraepithelial lesion (HSIL) (02 patients). Figure 3 summarizes the cytological lesions found.

There was a statistically significant relationship between parity and smear result with $\mathrm{p}<0.01$ (Table 1 ).

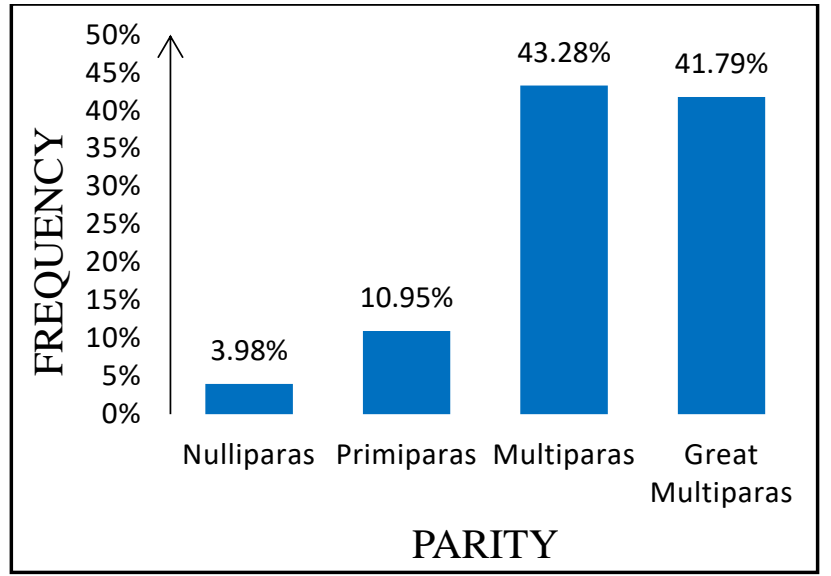

Figure 2: Parity.

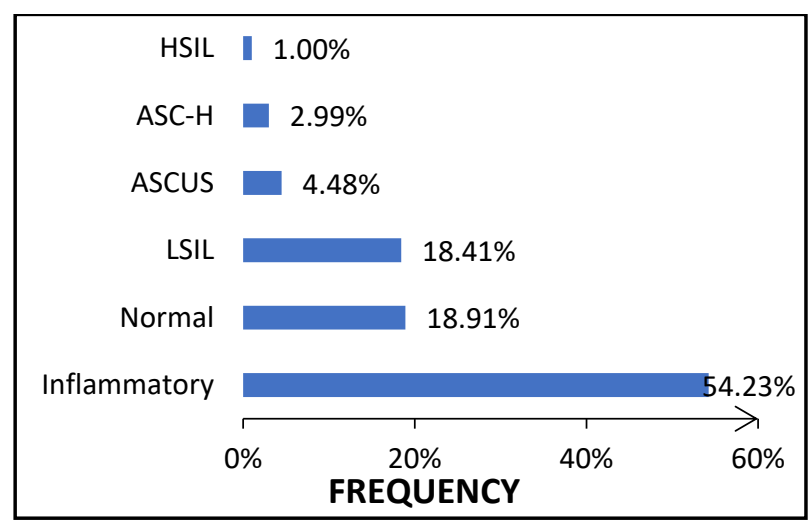

Figure 3: Result of cervico-uterine smear.

Table 1: Smear result.

\begin{tabular}{|c|c|c|c|c|c|c|c|c|}
\hline \multirow{3}{*}{ Variables } & \multicolumn{8}{|c|}{ Smear results } \\
\hline & \multicolumn{2}{|c|}{ Normal } & \multicolumn{2}{|c|}{ Inflammatory } & \multicolumn{4}{|c|}{ Pathological } \\
\hline & $\mathbf{N}$ & $\%$ & $\mathbf{N}$ & $\%$ & $\mathbf{N}$ & $\%$ & Total & P value \\
\hline Age group (years) & & & & & & & & 0.65 \\
\hline$\leq 35$ & 18 & 20.2 & 45 & 50.6 & 26 & 29.2 & 89 & \\
\hline$>35$ & 20 & 17.9 & 64 & 57.1 & 28 & 25.0 & 112 & \\
\hline Parity & & & & & & & & $<0.01^{*}$ \\
\hline Large multiparous & 7 & 8.3 & 52 & 61.9 & 25 & 29.8 & 84 & \\
\hline Multiparous & 26 & 29.9 & 39 & 44.8 & 22 & 25.3 & 87 & \\
\hline Primiparus & 5 & 22.7 & 14 & 63.6 & 3 & 13.6 & 22 & \\
\hline Nulliparous & 0 & 0.0 & 4 & 50.0 & 4 & 50.0 & 8 & \\
\hline
\end{tabular}

\section{DISCUSSION}

We had collected 201 smears, several Senegalese studies whose duration was approximate to our study reported the same number of cases collected. This was the case of the work carried out in Mbao in the suburbs of Dakar by Sy et al on 202 women in March 2011. ${ }^{11}$ On the other hand, in another Senegalese study conducted in Dakar, one of the Ndiadé for the same duration, 1533 cases were collected. ${ }^{12}$ These results show that a study conducted outside the capital city hardly achieves a significant number of screenings. The study conducted by Afoutou et al in the
Senegalese capital testifies to this fact, as during the first year of the study 1437 screenings were performed. ${ }^{13}$ The much larger demography in the capital than in the other localities could explain this large difference in numbers. However, we can add that Diourbel remains the region with the lowest female school enrolment rate in Senegal, which makes access to information on screening difficult and implies the need to insist on an adapted sensitization, particularly in the national language, for the female population in general. ${ }^{14}$ 
Outside of the capital in African countries, we did not find the same realities as ours, as studies conducted in Côte d'Ivoire and Cameroon show respectively 9853 cases from 2002 to 2006 and 587 cases in $2000 .^{15,16}$ These studies conducted outside the respective capitals collected many more cases despite the fact that the cities where these studies were conducted are much further away from their respective capitals. In France and Morocco, studies were conducted on a larger number of women than in Diourbel, including 9,334 women in the Bouche du Rhône 32,979 women in Morocco. ${ }^{17,18}$ This could be explained by the fact that in these countries, important means of sensitization, sometimes from door to door, have allowed a large study population. Our study was conducted in women aged from 15 to 64 years. The average age was 38.41 years. The most represented age group was between 30 and 40 years old with a rate of $32.34 \%$.

Several studies have a population whose maximum age does not exceed 70 years, as in our study, this was the case of the study in France in Bouche du Rhône conducted in 2011 where women are aged between 35 and 69 years. ${ }^{17}$ On the other hand, in several Senegalese studies, the study population also included women over 70 years old, which is what we find in the studies of Ndiadé where the age of women was between 20 and 80 years old as well as the work carried out in Mbao Dakar by Sy et al where women were aged between 18 and 88 years old and finally in the one of Diallo et al where the age of women was between 13 and 83 years old. ${ }^{11,12,19}$ Studies that have taken women over 70 years of age show no dysplastic lesions in these older women. In our study $29.2 \%$ of the pathological smears were found among women under 35 years of age. It is important to focus on this age group as these results may be explained by the fact that women under 35 years of age are more prone to repeated infections and repeated pregnancies.

Our study showed that $29.8 \%$ of the pathological smears concerned large multiparous women and $25.3 \%$ for multiparous women, this result revealed that parity is a factor favoring the occurrence of precancerous lesions. It is therefore necessary to step up the fight against cervical cancer by concentrating on this age group of the population, i.e. the under-35 years.

The smear results were classified according to the Bethesda system. Low grade LSIL dysplasia represented $18,41 \%$ in our series, which was close to the Diallo rate of $17.56 \%{ }^{19}$ Atypical squamous cells undetermined significance (ASC-US) were $4.48 \%$, similar to Afoutou's $4.61 \% .^{13}$ This was an acceptable rate, although it could have been reduced by avoiding leucorrhoea deposited on the cervix at the time of sampling. In general, these lesions are often correlated with inflammatory dystrophies. HSIL accounted for $1 \%$ of the smears; Gnaoui found a higher rate of $21 \%$, meaning 198 patients. ${ }^{18}$ The number of highgrade lesions was decreasing because the cervix usually presents lesions such that a smear is avoided and the biopsy is carried out directly. In most of the smears we performed, the cervix was macroscopically healthy $61.19 \%$.

\section{CONCLUSION}

Cervical cancer is one of the most fatal cancers in women, responsible for more than 270,000 deaths worldwide annually. Cervical cancer screening campaigns in several countries, particularly in developing countries, have contributed to a decrease in the incidence and mortality from cervical cancer. In Senegal, despite the various awareness campaigns, the number of women coming to our centers for screening is still modest. Generally speaking, the majority of the female population has a fatalistic attitude towards the occurrence of cervical carcinoma, which they consider incurable. Because of their modest income, the poorest do not undertake to be screened regularly.

\section{Funding: No funding sources}

Conflict of interest: None declared

Ethical approval: The study was approved by the Institutional Ethics Committee

\section{REFERENCES}

1. World Health Organization (WHO). Cervical Cancer Control; A Guide to Essential Practices. Second Edition.2014.2017. Available at: https://apps.who.int/iris/bitstream/handle/10665/254 713/9789242548952-fre.pdf.

2. Anaes (Agence nationale d'accréditation et d'évaluation en santé). Evaluation de l'intérêt de la recherche des papillomavirus humains (HPV) dans le dépistage des lésions précancéreuses et cancéreuses du col de l'utérus. 2004. J Gynecol Obstet Biol Reprod 2005;34:166-9.

3. Ferlay J, Steliarova-Foucher E, Lortet-Tieulent J, Rosso S, Coebergh JW, Comber H, et al. Cancer incidence and mortality patterns in Europe: estimates for 40 countries in 2012. Eur J Cancer. 2013;49(6):1374-403.

4. Gabrielli S, Maggioni E, Fieschi L. Cervical cancer prevention in Senegal: an International Cooperation. Project Report Acta Biomed for Health Professions. 2018;89(6):29-34.

5. Plummer M, DE Martel C, Vignat J, Ferlay J, Bray F, Francheschi S. Global burden of cancers attributable to infections in 2012: a synthetic analysis. Lancet Glob Health. 2016;4:609-16.

6. Gillison ML, Chaturvedi AK, Anderson WF, Fakhry C. Epidemiology of human papillomavirus-positive head and neck squamous cell carcinoma. J Clin Oncol. 2015;33:3235-442.

7. Bryan JT, Buckland B, Hammond J, Jansen KU. Prevention of cervical cancer: journey to develop the first human papillomavirus virus-like particle vaccine and the next generation vaccine. Curr Opin Chem Biol. 2016;32:34-47. 
8. Cutts FT, Francheschi S, Goldie S, Castellsague X, de Sanjose S, Garnett G, et al. Human papillomavirus and HPV vaccines: a review. Bull World Health Organ. 2007;85:719-26.

9. International Agency for Research on Cancer (IARC)/World Health Organization (WHO). Globocan 2012: Cervical Cancer Estimated Incidence, Mortality and Prevalence Worldwide in 2012. Lyon, France; IARC. 2012. Available at: http://globocan.iarc.fr/old/FactSheets/cancers/cervixnew.asp. Accessed on: 25 July 2020.

10. Dayyani F, Etzel CJ, Liu M, Ho CH, Lippman SM, Tsao AS. Meta-analysis of the impact of human papillomavirus (HPV) on cancer risk and overall survival in head and neck squamous cell carcinomas (HNSCC). Head Neck Oncol. 2010;2:15.

11. SY DM, Faye O, Mbaye EHS, Diallo AS, Gueye MV, Diop N, Dem A. Dépistage primaire de cancer du col de l'utérus par frottis cervico vaginal et typage HPV dans le district de Mbao au Sénégal. Journal de Biologie Clinique. 2016;9-13.

12. Ndiade A. Bilan du dépistage cytologique en 2016 par frottis cervico vaginal au laboratoire d'histologie embryologie et cytogénétique du chu Le Dantec. Ucad mémoire Numéro. 2016;283:41-4.

13. Afoutou JM et al. Une décénie de dépistage colpocytologique Journal des sciences. 2008;8:21-6.

14. Wikipedia, the free encyclopedia. Cervix. 2014. Available at: https://fr.wikipedia.org/wiki/Col_de_1\%27ut\%C3\%A 9rus. Accessed on: 25 July 2020.
15. Tebeu PM, Sandjong I, Nkele N, Fokoua A, Achu P, Kuam L, et al. Lésion précancéreuses du col utérin étude transversale. Médecine d'Afrique Noire. 2005;51(1):28-31.

16. N'guessou K, Kouakou F, Loué V, Angoi V, Abauleth Y, Boni S. Le cancer du col de l'utérus aspects épidémiologique et prise en charge en milieu africain, mali médical 2009 tome XXIV. Le Mali Médical. 2009;3:1-2.

17. Piana L, Leandri FX, Retraite L, Heid P, Tamalet C, Garnier HS. L'auto prélèvement vaginal à domicile pour recherche de papilloma virus à haut risque: campagne expérimentale au département de bouches du Rhones. Bull Cancer. 2011;98:723-31.

18. Gnaoui NEL, Saile R, Benomamar H. Pap smear an inevitable test in the screening of the lesion of the cervix. J Afr Can. 2010;2(9-13):12.

19. Diallo AS, Fenton CE, Afoutou JM, Giao MS. Condylomes, dysplasies et carcinomes du col utérin : notre expérience en vingt ans (1980-1999). Dakar Médical. 2003;48(3):181-4.

20. Okonofua F. Prévention et contrôle du cancer du col en Afrique: Appel à l'action. Af $\mathrm{J}$ Reprod Health. 2015;19(1):11-3.

Cite this article as: Ndiade A, Thiam I, Diallo AK, Diatta AL, Senghor F, Faye O. Epidemiological and cytological aspects of the cervix in women from the Diourbel region (Senegal) cervical smear screening. Int J Reprod Contracept Obstet Gynecol 2020;9:435660. 